\title{
Study on the Complementation and Harmony of Zhongnan Culture with Confucianism, Buddhism and Taoism
}

\author{
Hongqiao Song \\ Xi'an Fanyi University \\ Xi'an, China
}

\begin{abstract}
In the long history of China, Confucianism, Buddhism and Taoism culture runs through the mainstream values of the Chinese nation for thousands of years with its strong moral and ethical awareness as well as political management thought. Its root cause is tightly bound to the Zhongnan Culture. Western Zhou Dynasty built its capital at the foot of Zhongnan Mountain, established the ritual system, which become the origin of Confucian morality. There are eight schools of Chinese Buddhism, of which six are originated in Zhongnan Mountain. Taoism originator Lao Tzu realized enlightenment and preached in Zhongnan Mountain, and wrote five thousand words of "Tao Te Ching" at Louguantai. The inclusive exchange, mutual influence and improvement of traditional Chinese Confucianism, Buddhism and Taoism in Zhongnan Mountain area reflect the integration and long-lasting of Zhongnan culture.
\end{abstract}

Keywords-Zhongnan culture; Confucianism; Buddhism; Taoism; harmony

\section{INTRODUCTION}

Zhongnan Mountain of Guanzhong is located in the central area of Qinlong culture. "Shangshu • Yu Gong" has mentioned the word of "Zhongnan", "The Classic of Mountains and Seas" referred it as "Nanshan". Since Western Zhou Dynasty, Qin, Han, Sui and Tang Dynasties and other thirteen dynasties built their capital in the north of Zhongnan Mountain. As the birthplace and spreading place of Chinese culture, Zhongnan Mountain developed into the ancient Chinese Yellow River Cultural Center, and the integration of core elements of Chinese culture, which was known as "cradle of Chinese civilization." Zhongnan Mountain, what we say today, as for the common characteristics of natural geography and cultural activities, refers to Shaanxi Guanzhong area of Qinling Mountains and the Weishui drainage basin at its north, namely the middle section of Qinlin Mountains with its west from Wugong and ends at Lantian to the east. As the birthplace of national culture, Zhongnan culture follows the same strain and continues for thousands of years. Its content is broad, profound and long-lasting, integrating the core content and elements of traditional Chinese Confucianism, Buddhism, and Taoism. In the long history of China, Confucianism, Buddhism and Taoism culture runs through the mainstream values of the

Fund Project: Shaanxi Province soft science research funded research project of "Research on Management Thought in Zhongnan Folk Culture" (2015KRM162).
Chinese nation for thousands of years with its strong moral and ethics and political management ideas. Its root cause is tightly bound to Zhongnan Culture. This paper begins with the historical origins and relationships of Zhongnan culture and the Confucianism, Buddhism and Taoism, to offer a few of the author's humble opinions.

\section{ZHONGNAN CULTURE AND CONFUCIANISM}

Confucianism, represented by Confucius doctrine, has been spreading in China for thousands of years. The ancient saying goes: "half" the Analects of Confucius" rules the country", which fully illustrates the position and role of Confucius and Confucianism created by Confucius in the minds of the Chinese people, as well as the influence on China's politics, economy and culture over two thousand years. The core of Confucius Confucianism comes from the Rites of Zhou, which was born in the capital of Western Zhou Dynasty, namely Fengjing and Haojing. According to research, Feng Hao site is located at both sides of Fenghe River in the area of Mawang Town and Doumen Town of Chang'an District in the north of Zhongnan Mountain. Fengjing is in the west of the river, and Haojing is in the east, both of them are collectively referred to as Feng Hao. Feng Hao is the first capital with a strict planning in the history of China.

Feng Hao is the political, economic and cultural center of the Western Zhou Dynasty. The political system, ritual culture, ideological doctrine, literature and art, the bronze inscriptions, etc. of the Zhou Dynasty are produced, developed and continued in Feng Hao. In Feng Hao, Zhou Gong established the patriarchal system first of all containing both political power rules and kin moral constraints, and established pyramid-style strict rule for the emperor, princes, ministers and scholars; and developed rites and music and established the ritual system to fix the hierarchy relationship. Therefore, Zhou culture is a kind of "rite-respecting culture" (Fan Wenlan "General History of China" First Volume). The contents of rite contain "Qin Qin" that implements the principle of blood clan which means to be close to those should be close to, and "Zun Zun" that executes the principle of political relations which means to respect who should be respected. ${ }^{[1] \mathrm{P} 4}$ Because Boqin, the eldest son of Zhou Gong, was granted in Lu representing Zhou Gong, so the rite of Zhou was completely brought to Lu. The rites of Zhou followed by $\mathrm{Lu}$ directly developed the 
Confucian school with Confucius as the representative. Confucius respected the Rites of Zhou:"the Rites of Zhou is established by referring to that of Xia and Shang dynasties, which is rich and complete, so I follow the system of Zhou!" (Analects of Confucius - Ba Yi). In the Spring and Autumn period, the Rites of Zhou was advocated strongly to restrain and deal with the relationship between people, advocating "restraining ourselves to the degree of conforming to the Rites of Zhou can achieve the state of benevolence" "do not watch, listen to, talk about or perform those do not conform to etiquette" (The Analects of Confucius - Yan Yuan), to build the way of etiquette as a social model, the way to be gentleman as the personality model, and the golden mean of behavior pattern. [1]P4 Confucius advocated "rites" and laid the theoretical foundation for China to be a state of etiquette. During the Western Han Dynasty, Emperor Wu of the Han Dynasty adopted the proposal of Confucianist Dong Zhongshu and established the dominant position of Confucianism through "rejecting all kinds of theoretical schools but Confucianism," and various dynasties after Tang Dynasty all took Confucianism as the way of governing the country. Therefore, it can be said that Zhongnan mountain area is the birthplace and spreading place of Rites of Zhou. Although Confucianism was generated in $\mathrm{Lu}$, its ideas were derived from Zhongnan Mountain.

Ever since Zhou, Qin and Han dynasties, Zhongnan mountain area had played a very important role in the promotion of Confucianism. Ma Rong, the Confucianist of Eastern Han Dynasty, studied with the famous scholar Zheng Xuan at Zhongnan Mountain when he was young. He devoted himself to the study of Confucian classics, and then spread Confucianism in Guanzhong with students of more than 400; the famous Confucian master Zheng Xuan also studied the Confucian classics in Zhongnan Mountain, which laid his position in Confucianism. ${ }^{[2] \mathrm{P} 54}$ During the period of Han Dynasties, "old and well-known families were fond of rites" indicated that the etiquette of western Zhou still formed the Confucian classics family in the social environment at that time, and a number of Confucian classics masters emerged, such as Ma Rong, Jia Kui, Zhao Qi, Feng Bao and Yang Zhen. These scholars wrote either classics or history and concerned about social politics, making contribution with regional characteristics for the prosperity of academic thinking of Eastern Han Dynasty. During the Northern and Southern Dynasties, the Northern scholars inherited the old theory of Confucianism of Han Dynasty and shouldered the cultural mission of educating alien people with the active attitude towards life to save the value of Han culture. With the gradual improvement of the imperial examination system of the Tang Dynasty, the court employed the scholars through imperial examinations, regardless of identity status, opened career to all talents, which also inspired the political enthusiasm of Zhongnan scholars to join in the construction of Chinese culture. Liu Zongyuan committed to social reform, Du You wrote "Tong Dian", highlighting the important significance of economic election in national politics; Du Mu offered notes for 13 chapters of Sun Zi's The Art of War, paying attention to the study of military and other military affairs, summing up the experiences and lessons for strengthening the country and people, which were the inheritance and development of
Zhongnan culture. Zhang Zai of Song Dynasty gathered students and advocated Confucianism at Hongqu Academy in Zhongnan Mountain, becoming the founder of "Guan School" and a master of Confucian Thought. His thoughts and writings had been regarded as one of the bases for governing the country, selecting talents and the required books of imperial examinations by the governments of Ming and Qing dynasties. The academic research, theoretical achievements and rules for governing a country and so on highlight the inclusiveness and diversity of Zhongnan culture, so that Zhongnan culture contains both the official culture of Confucianism, namely "try to let others be benefited in success", and the seclusion culture, namely "protect ourselves in poor", providing pure land to the aggressive people and the retired ones of various dynasties to cultivate their moral character and nature.

Cheng Hao of Song Dynasty praised "Guanzhong people learn language and politics, discuss politics and the knowledge about rites, music, military and punishment, all the people are interest in learning", Zhang said, "the value of learning lies in its usefulness". Zhongnan scholars were committed to the study of art of war and well-field system, which was the inheritance of practical use spirit, but also the expression of Confucianism's active attitude toward life. Obviously, Confucianism and Zhongnan culture can be seen in each other through cohesion, and had penetrated into the daily life of people in Zhongnan area and advanced with the times. Today, it still has a significant impact on the mainstream cultural consciousness, thought form and ethics of Shaanxi Zhongnan area and even the Chinese society.

\section{ZHONGNAN CULTURE AND BUDDHISM}

Zhongnan Mountain is the main birthplace of Buddhism after the Buddhism has been transmitted to the east. ${ }^{[3] \mathrm{P} 100}$ Take Zhongnan Mountain as the center, and from west to east, take Guifeng Mountain, Qinghua Mountain, Xiaowutai Mountain, South Wutai Mountain, Cuihua Mountain, Jiawutai Mountain, Taixing Mountain and other mountains as the coordinates, to form the dotted temple group. There are forty or fifty famous temples include Xingjiao Temple, Xiangji Temple, Caotang Temple, Jingye Temple, Fengde Temple, Tianchi Temple, Xingqing Temple, Guoqing Temple, Xilin Temple and Mituo Temple. Ancient poetry says: "Both Chang'an and Zhongnan have profound historical accumulation of Buddhism". [4]P317

Among the eight great Buddhist schools of Chinese Buddhism formed in the Sui and Tang dynasties, except Tiantai Sect and Zen grew up in Shaoxing, Zhejiang Province and Songshan, Henan Province, the other six were originated in Zhongnan Mountain, the Three Treatises School patriarch's court was in the Caotang Temple, the Pure Land Sect patriarch's court was in the Xiangji Temple and Wuzhen Temple, Faxiang Sect patriarch's court was in the Great Ci'en Temple, Huayan School patriarch's court was in the Huayan Temple, the Vinaya School patriarch's court was in Jingye Temple and Fengde Temple, Vajrayana patriarch's court was in the Daxingshan Temple. China's earliest officially ordered Guanyin Taoist Taoist rite was in South Wutai; the country's largest Buddhist clay sculpture group was in Shuilu Nunnery. Wei Lue, notes of Wei Zhi made by Pei Songzhi says that "in the first year of Yuanshou, Ai Emperor of Han Dynasty, the 
king of Dayuezhi dispatched Yi Cun to teach Jing Lu, a learned scholar in Chang'an, Fu Tu Jing orally", which was half a century earlier than the preach in Yongping, Eastern Han Dynasty. Shortly thereafter, the base of Hong Teaching was started to be built in Zhongnan Mountain, that is, Luohan Temple in Pang Village within the territory of Hu County at north of Zhongnan Mountain. The temple was built in the early years of Yongping of Eastern Han Dynasty (58-61), which was initially name as Baima Zhaojue Yuan. Emperor Hui of Western Jin Dynasty promulgated the imperial edict in the first year of Tai'an (302) to construct this temple. Now the imperial tablet still exists in the temple. Thereafter, the temple was expanded as Fragrance Court. [5]P240 During the Three Kingdoms period, Zhu Shixing set out from Yongzhou in the fifth year of Ganlu (260), to Khotan (now Hetian of Xinjiang) to seek "Da Ban Ruo Jing", indicating that at this time Buddhist communication activities had been existing in Yongzhou territory. During the sixteen-state period of the Eastern Jin Dynasty, the Zhongnan Buddhism entered the stage of great development. Caotang Temple under Guifeng of Zhongnan Mountain, as the first national site for translating the classics and the first administrative institution of national Buddhism affairs in the history of Chinese Buddhism, had become the base of Chang'an Buddhism. In the most prosperous Shengshou Temple at South Wutai under Zhongnan Mountain in Song Dynasty, the plaque inscribed by the emperor of Song Dynasty was in its internal, and it was also the place for the emperor to parade, conduct Buddhist practice and for people to worship and offer incense to Buddha. Since the introduction of Buddhism in the early Han Dynasty, and till it developed to the Tang Dynasty, Chang'an had been the center of Chinese Buddhism communication, the place for many monks' practice and seclusion as well as the patriarch's court of various Buddhism schools. ${ }^{[2] \mathrm{P} 56}$

$\mathrm{Hu}$ County at middle section of Zhongnan Mountain has the most Buddhist temples from ancient times till now. Until today, Guanyin Taoist rites in Hu County still offer lectures about Buddhism on the first and fifth day of lunar month. People from the surrounding areas go to listen to Buddhist scriptures voluntarily. The important temples of Buddhism in Zhongnan Mountains are still well-protected, such as Shuilu Nunnery within Lantian territory, is known as the "second Dunhuang". The Nunnery contains more than 3700 statues of Buddhas and Bodhisattvas as well as Confucianists, Taoists and doctors, having high artistic value and historical value; Famen Temple in Fufeng County under Zhongnan Mountain becomes the world-famous Buddhist secret site and sign because the Sheli, the finger bone of Buddha Sakyamuni is stored there. In various major temples in Zhongnan Mountain, the great virtue of eminent monks who transmit and explain classics can also be referred to as the best. "Monk Biography", "Continued Monk Biography" and "Monk Biography of Song Dynasty" recorded that the eminent monks in Zhongnan were up to hundreds. They were the founder of a Buddhist sect, or were known for a certain Buddhist theory, or had played an important role for the reconstruction and revitalization of Buddhism temple. All of these are enough to prove that the lofty status and influence of Buddhist culture in Zhongnan area in the entire China's Buddhist circle.
Chinese Buddhism developed to its heyday in the Sui and Tang Dynasties and spread to East Asia and other places with foreign exchanges. Japanese Nichiren Shu was created according to the "Lotus Sutra" taking Caotang Temple as patriarch's court. The Pure Land believers of Japan's Buddhism took Xiangji Temple of Shan Dao Ta Yuan in Zhongnan Mountain as the patriarch's court; the most famous was Monk Yixiang of Xinluo Country (now the Korean Peninsula) learned Buddhism and practiced in Zhongnan Mountain; Master Tang Xuanzang was known as the "perfect man in the history", enjoying the reputation of "Jie Tuo Tian" "Da Cheng Tian" in India. He is the "first world cultural celebrity" name by United Nations for China ${ }^{[4] 450}$. It can be seen the farreaching influence of Zhongnan Buddhism.

\section{ZHONGNAN CULTURE AND TAOIST SCHOOL AND TAOISM}

Zhongnan Mountain was worshipped by the Taoist School and Taoism as the crown of the cave. Taoist ancestor Lao Tzu attained enlightenment and expounded the texts of Taoism in Zhongnan Mountain, and he was buried here. Tao Te Ching, the core of Taoism derived from Louguantai. Therefore, Zhongnan Mountain became the birthplace of Taoist school and Taoism. Although Lao Tzu did not set up religious sect, he created the philosophy of Taoism. So Tao Te Ching was observed by various persons in charge of Taoism and the followers as the valuable book and theoretical basis of Taoism.

Taoism culture, as a native religious culture of China, embodies the broad human care and strong national characteristics, having far-reaching influence on all levels of Chinese national culture. The beginning of Taoism in Zhongnan Mountain can be traced back to the time when Lao Tzu came to preach the teachings. Louguantai is located in the mountains of Zhongnan Town at south of Zhongnan Mountain. According to legend, the leader of Hanguguan of Zhou Dynasty ordered Yin Xi "to make a building with straw for viewing the astronomical phenomena" here, which was the first one. So it was named as "Lou Guan". Lao Tzu came to Hanguguan to Yin Xi the classics at the South Building. The building for teaching classics also called Louguantai. Lou Guan Taoist School was formed in the Northern Wei Dynasty. Louguan Biography recorded that in the first year of Xianxi during Yuan Emperor of Wei Dynasty (264), Taoist Liang Chen studied with Master Zheng at Louguan, which proved that Louguan had been formed at that time and the Taoist activities already existed. After the completion of Louguan, Liang Chen taught the "Ri Yue Huang Hua Shang Jing" and so on, naturally the master Taoist of the Northern Dynasties preferred Louguan. During the Northern and Southern Dynasties, Taoism in Zhongnan Mountain had a new development. During the Northern Dynasties, master Taoists such as Wang Fu, Wang Yan, Yan Da and so on cultivated themselves here, and formed the sect, which was Louguan School. As a result, Louguantai became the Taoist activity center and an important place for expounding the classics. In the first year of Duan Gong (988), Taizong of Song Dynasty ordered to change Zongsheng Guan of Zhongnan Mountain Louguantai as Shuntianxingguo Guan, and personally wrote the plaque. And he constructed Taipingxingguo Guan in 
Zhongnan (now Zhongnan Town) to make Louguan Taoism increasingly prosperous. ${ }^{[6] \mathrm{P} 491,501}$

Taoism reached its peak in the Tang dynasty, and its status was set above Buddhism. At the beginning, Chen Tuan, Lv Dongbin, Liu Haichan, Zhang Wumeng and others resided in the mountain and cultivated themselves according to the religious doctrine. Till the Jin and Yuan Dynasties, Wang Chongyang, native of Xianyang of Shaanxi, attained the enlightenment after secluded in Zhongnan Mountain and created Quanzhen Sect, taking Zhongnan Mountain area of western Chang'an as the center, coving Guanlong and the vast northern region. After his death, he was buried in Liujiang Village in the north of Zhongnan Mountain (now Zu'an Town of Hu County). This place was built into Quanzhen holy land, the Chongyang Palace. [7]P239 Quanzhen Sect reached its heyday when controlled by Qiu Chuji. The Taoist temples were built in Zhongnan Mountain and even the whole country. Till the twenty-fifth year of Yuan Dynasty (1288), the number of Taoist temples reached 5048. As a result, Zhongnan Mountain area was known as the Taoist prosperous place. Zhang Qingzhi, the ninth ancestor Puji master of Zhendadao, which was created in Cangzhou earlier than Quanzhen Sect, was a native of Ganzhou of Shaanxi. He performed his activities in Huashan, Taibai Mountain area for a long term, and the Zhendadao Palace had been established in Chang'an, Fufeng and other places. After the efforts of Quanzhen Sect and Zhendadao, by the end of Jin Dynasty, 91 Taoist temples were newly built in the northern area of Qinling, Shaanxi. During the Ming and Qing Dynasties, the Taoist temples in Zhongnan area mainly included the Louguantai and Chongyang Wanshou Gong under the famous Taoist Mountain, Zhongnan Mountain, as well as the Yuquan Yuan, Dongdao Yuan, Xidao Yuan, Zhenyue Gong and Yuntai Guan of Huanshan. Taibai Mountain was the Spirit Mountain for Taoist to gather together, and there were 108 Taoist temples distributed on the mountain. At that time, Baxian An in the city of Xi'an had developed into one of the ten Conglin of Taoism. And taking the advantage of its superior geographical location, it had become the most influential Taoist temple in Shaanxi and the Taoism communication center in Northwest region.

The classic theory of Taoism was originated in and spread from Louguantai at the north of Qinling. But the Taoist organization was first generated in Hanzhong at the south of Qinling, and its actual activities also started here. So we can say that Zhongnan Mountain area was the site for idea, culture and religion, having strong force of penetration and radiation. ${ }^{[2] \mathrm{P} 58}$

\section{INTEGRATION OF ZHONGNAN CULTURE WITH CONFUCIANISM, BUDDHISM AND TAOISM}

Zhongnan culture integrates traditional culture, religious culture, political culture and folk culture, embodies and deduces the integration and compatibility of Chinese culture with its unique geographical location, production mode and social organization, which is long lasting yet fresh.

From the history of China, since ancient times to various later dynasties, the emperors all pursued harmony. The hundred schools of thought during the Spring and Autumn period, although their theories were different, they were all dissatisfied with the years of war, and all longed for the harmonious and stable "unified" society. This cultural phenomenon and political system were highlighted in Zhongnan area, which was the place of capitals of thirteen dynasties.

The Western Zhou Dynasty unified various tribes, built its capital in Fenghao under Zhongnan Mountain, and established a strict ritual system. Since then, Zhongnan Culture began to reveal clues of system culture. To the Qin and Han dynasties, the Chinese feudal unified political system was firmly established, and officially ushered in the political and cultural history of ancient capitals of thirteen dynasties. In the early Han Dynasty, Emperor Wen selected Huang-Lao's "quiet and inaction" for governance. At this time, the Taoist School of Huang-Lao had absorbed some ideas of Confucianism (Tang Yijie, Freedom and Order Confusion - Huainanzi Research, Preface). Emperor Wu of Han Dynasty adopted the political proposal of learned Confucianism scholar Dong Zhongshu "dismiss the one hundred schools except Confucianism". But at that time, Confucianism had learned more of Huang-Lao, Yin and Yang, Legalism and other thoughts. ${ }^{[8]}$ P4 Emperor Xuan advocated "merging of various thoughts" (Han Shu - Record of Emperor Yuan), integrating various schools in policy. At the end of Western Han Dynasty, Buddhism was introduced into China, and the rulers of the Han dynasty also thought that it was only one of many Taoist magic arts and religious without imposing control on it. Till Sui and Tang dynasties, Confucianism, Buddhism and Taoism were evenly matched with each other, but regardless of the emperor's worship for Taoism or Buddhism, its cultural system always took the politicized Confucianism as the core; the debates among various schools about whether Buddhism or Taoism was the first were also conducted under the political system at that time. This kind of "three-religion-balance" sponsored and intervened by the government not only helped to eliminate the violent conflicts among various schools, but also provided a strong guarantee for shaping and consolidating the culture in southern area. In this way, Zhongnan culture had profound political connotation and rich cultural resources. So Zhongnan area epitomized the Chinese culture and became one of the most important birthplaces of Chinese culture.

If Chang'an culture is regarded as the "court culture", it represents the majesty and royal rule of Zhou, Qin, Han and Tang dynasties; if Guanzhong culture is regarded as "courtyard culture", it is the infiltration, diffusion and extension of Chang'an culture in the surrounding area. Then, Zhongnan culture is undoubtedly a kind of "back garden culture" which is tranquil and quite for self-cultivation, having both the official spirit of Confucian "in success, try to let others be benefited", and the seclusion thinking of Buddhism and Taoism "in poor, try to protect ourselves", so that the scholars and men of letters of various dynasties can always be calm and free in the political struggle, interest choice and the conflicts in personal values. The reason why Zhongnan culture was able to integrate Confucianism, Buddhism and Taoism was its unique geographical location and natural environment. Zhongnanshan Mountain stretches over hundreds of miles and runs through the east and west of China. Go north about 50 miles, then the 
official culture of Chang'an political center can be enjoyed, and return to the south, people can also appreciate the tranquil secluded culture of Zhongnan Mountain. For the ancient scholars, if not living in the capital, then return to live in the mountains. Zhongnan Mountain faces Chang'an City with convenient transportation, which is an ideal "paradise." Secluded in this place to obtain the emperor's blessing may after all be accepted as the "Zhongnan Shortcut" for being an official. As a holy land for seclusion, Zhongnan Mountain is close to the power center of imperial capital. The superior geographical location gives the shortcut the specific political and geographical special significance. On the one hand, it combines the naturalness and sociality of human perfectly; on the other hand, it connects the political path and ideal of life closely. Therefore, the official culture and seclusion culture integrated by Zhongnan Mountain is the natural combination of Confucianism advancement and Buddhism backwardness.

In short, during the period when Zhongnan area was serving as capitals of thirteen dynasties, Confucianism, Buddhism and Taoism all had different degrees of inclusiveness and reconciliation. Confucianism advocated "ways run parallel without interfering with one another", Taoism advocated "tolerant", Buddhism with Chinese characters also advocated the inclusiveness between different religious ideas. [ ${ }^{8] \mathrm{P3}}$ Various schools and sects all absorbed other cultures for self-cultivation and self-improvement consciously and constantly in the long-term controversy and conflict, and ultimately created the characteristics of Zhongnan area, namely cultural diversity, inclusiveness, intersection and compatibility.

\section{CONCLUSION}

Zhongnan culture was originally a culture with strong regionalism, but because Feng, Hao, Xianyang, Chang'an had served as the capitals of thirteen dynasties, so the customs, aesthetic taste and cultural etiquette of Zhongnan area not only led the mainstream culture of Central Plains, but also were followed by the minorities at the frontier. Moreover, the core of Chinese traditional culture, Confucianism, Buddhism and Taoism, was either originated or gathered in Zhongnan area, so the Zhongnan regional culture turned into synonymous of Chinese culture, became the mainstream culture and social ideology of Chinese nation before Song Dynasty. Therefore, it can be said that Zhongnan culture is an important aspect of the Chinese culture before Tang Dynasty, and specimen and living fossil for the study of traditional Chinese culture. Mr. Liang Shuming said: "on the one hand, Chinese culture clearly has the very great power, and on the other, we truly and really cannot point out where its power lies in." ${ }^{[9] P 10}$ Chinese culture is such, and Zhongnan culture is no exception. Therefore, to explore the theoretical meaning and essence of Zhongnan culture, we should extract the factors and elements of Zhongnan Culture from the traditional Chinese culture. To clarify the Confucianism, Buddhism and Taoism contained in or applied by or reflected by Zhongnan culture, scholars in various fields are needed to provide their different views.

\section{REFERENCES}

[1] Li Zhihui. Exploration on Zhongnan Cultural Tradition [J]. Shaanxi Zhongnan Cultural Studies, 2014 (6) : 4-6.

[2] Lai Bonian. Zhangnan Mountain is the Most Important Birthplace of Chinese Culture [J].Journal of Xi'an Fanyi University, 2011 (4) : 5258.

[3] Wang Xiaoru. Study on Cultural Resources in Zhongnan Mountain Area in Song Dynasty [J]. Tangdu Journal, 2007(1): 97-101.

[4] $\mathrm{Xi}$ 'an Committee of Chinese Literature and History DataXijing Buddhism [M].Xi'an: Shaanxi People's Publishing House, 2000(6):45,317-342.

[5] Hu County Cultural Relics Record Compilation Committee. Hu County Cultural Relics Record [M].Xi'an: Shaanxi People 's Education Press, 1995(12):85-92,202-249.

[6] Wang Anquan. Records of Zhouzhi County [M].Xi'an: Sanqin Publishing House, 1993(8):490-503.

[7] Shen Kuo. Publication of Yuan Dynasty Mengxi Bitan [M].Beijing: Cultural Relics Publishing House, 1975(12):236-240.

[8] Tang Yijie. Confucianism, Buddhism and Taoism and Chinese Traditional Culture [M].Beijing: Encyclopedia of China Publishing House, 2013(7):2-9.

[9] Liang Shuming. Main Points of Chinese Culture [M].Shanghai: Shanghai Century Publishing Group, 2005(5):9-27. 